\title{
Program remedial dan angka putus studi mahasiswa kedokteran
}

\author{
Revalita Wahab, ${ }^{1}$ Purnamawati Tjhin ${ }^{2}$
}

\begin{abstract}
ABSTRAK
\section{LATAR BELAKANG}

Walaupun penyusunan kurikulum Pendidikan Kedokteran telah disusun sedemikian rupa supaya dapat menghasilkan lulusan yang memiliki kompetensi yang ditetapkan, tetap ada mahasiswa yang mengalami putus studi. Prevalensi putus studi secara umum pada tahun 2017 sebesar 2.8\% mahasiswa yang terdaftar di Perguruan Tinggi Swasta dan Negeri di Indonesia mengalami putus studi dan 3.7\% mahasiswa terdapat di Jakarta. Putus studi dapat berdampak negatif untuk masyarakat, profesi dan institusi, sehingga perlu upaya untuk melakukan pencegahan dan penanggulangannya. Salah satu upaya yang dapat dilakukan adalah dengan melaksanakan program remedial. Penelitian ini bertujuan untuk menilai efektivitas program remedial dalam menurunkan angka putus studi mahasiswa kedokteran.
\end{abstract}

\section{METODE}

Penelitian dilakukan dengan desain cross-sectional pada 228 mahasiswa angkatan 2013-2017, menggunakan data sekunder meliputi jenis kelamin, tahun masuk kuliah, dan status putus studi. Kriteria inklusi sampel adalah mahasiswa yang termasuk pada kategori terancam putus studi. Analisis data dengan uji Chi-square, dengan tingkat kemaknaan 95\%.

\section{HASIL}

Prevalensi putus studi sebesar $12.7 \%$. Sebagian besar responden yang terancam putus studi berjenis kelamin perempuan (68.9\%) dan merupakan mahasiswa program non remedial (64\%). Tidak ada hubungan bermakna antara jenis kelamin dan angka putus studi $(\mathrm{p}=0.989)$. Perempuan dan laki-laki memiliki peluang yang sama untuk terjadi putus studi. Mahasiswa yang termasuk angkatan program remedial memiliki angka putus studi yang lebih tinggi (18.3\%) dibandingkan dengan mahasiswa yang termasuk angkatan non-remedial $(9.6 \%)$, walaupun secara statistik tidak bermakna $(\mathrm{p}=0.058)$.

\section{KESIMPULAN}

Prevalensi putus studi mahasiswa kedokteran tahun 2013-2017 sebesar $12.7 \%$. Tidak terdapat hubungan bermakna antara jenis kelamin dan program remedial dengan terjadinya putus studi.

Kata kunci: putus studi, mahasiswa kedokteran, program remedial
${ }^{1}$ Departemen Radiologi, Fakultas Kedokteran Universitas Trisakti, Jakarta, Indonesia

${ }^{2}$ Departemen Anatomi, Fakultas Kedokteran Universitas Trisakti, Jakarta, Indonesia

\section{Korespondensi:}

Revalita Wahab

Departemen Radiologi, Fakultas

Kedokteran Universitas Trisakti, Jakarta, Indonesia

Jalan Kyai Tapa (Kampus B)

Usakti, Grogol, Indonesia 11440

Email:

litawahab@trisakti.ac.id

J Biomedika Kesehat 2021;4(2):50-56 DOI: 10.18051/JBiomedKes.2021. v4.50-56

pISSN: 2621-539X / eISSN: 2621-5470

Artikel akses terbuka (open access) ini didistribusikan di bawah lisensi Creative Commons Attribution 4.0 International (CC-BY 4.0) 


\section{ABSTRACT}

\section{Remedial program and drop out numbers of medical students}

\section{BACKGROUND}

Even though the Medical Education curriculum has been structured in such a way as to produce graduates who have the specified competencies, there are still students who experience dropouts. The prevalence of dropping out of study in Indonesia in 2017 was $2.8 \%$ and in Jakarta was 3.7\%. Dropping out of studies can have a negative impact on society, professions and institutions, so it is necessary to take efforts to prevent and overcome them. One of the efforts that can be done is by doing a remedial program. This study aims to assess the effectiveness of remedial programs in reducing dropout rates for medical students.

\section{METHODS}

The study was conducted with a cross-sectional design on 228 students 2013-2017, using secondary data including gender, year of study, and dropout of study status. The sample inclusion criteria were students who were in the risk of being dropped out of school. Data analysis used Chi-square test, with a significance level of $95 \%$.

\section{RESULTS}

The prevalence of dropping out of the study was $12.7 \%$. Most of the respondents who were threatened with dropping out of study were female $(68.9 \%)$ and were students of non-remedial programs (64\%). There was no significant difference between gender and study dropout rate $(p=0.989)$. Women and men have the same chance of dropping out of studies. Students belong to the remedial class had a higher dropout rate $(18.3 \%)$ than students who were non-remedial $(9.6 \%)$, although it was not statistically significant $(\mathrm{p}=0.058)$.

\section{CONCLUSION}

The prevalence of dropping out of medical students in 2013-2017 was $12.7 \%$. There is no significant relationship between gender and remedial program with the occurrence of dropouts of study.

Keywords: dropout, medical student, remedial programme

\section{PENDAHULUAN}

Pada dua dekade terakhir, pendidikan kedokteran di Indonesia telah banyak mengalami perubahan, terutama pada strategi pembelajaran yang digunakan untuk memastikan lulusan institusi kedokteran memiliki standar kompetensi yang telah ditetapkan. Pada Buku Standar Kompetensi Dokter Indonesia (SKDI) tahun 2012, terdapat 7 area kompetensi yang hendak dicapai dan 725 daftar penyakit yang harus dikuasai oleh mahasiswa kedokteran pada akhir masa studinya. ${ }^{(1)}$ Selain mengacu pada SKDI, kurikulum pendidikan kedokteran di Indonesia wajib mengacu pada Standar Nasional Pendidikan Tinggi (SNPT), Kerangka Kualifikasi Nasional Indonesia (KKNI), dan Standar Nasional Pendidikan Kedokteran (SNPK). Acuan-acuan tersebut mengatur tentang berbagai standar seperti strategi pembelajaran yang harus digunakan pada pendidikan tinggi, termasuk pendidikan kedokteran, yaitu pembelajaran yang berpusat pada mahasiswa (Student Centered), mengedepankan Problem Based Learning, Community Based Learning, Early Clinically Exposure (Elective), dan bersifat Systematic. ${ }^{(2,3)}$

Walaupun telah dilakukan penyusunan kurikulum Pendidikan Kedokteran sedemikian rupa dan mempertimbangkan banyak hal supaya dapat menghasilkan lulusan yang memiliki kompetensi yang telah ditetapkan, tidak semua mahasiswa kedokteran dapat menyelesaikan pendidikannya tepat waktu. Sampai saat ini, tetap terdapat mahasiswa yang mengalami putus studi. ${ }^{(4)}$ Pada tahun 2017 tercatat 195.176 orang atau sebesar $2.8 \%$ dari jumlah mahasiswa yang terdaftar di Perguruan Tinggi Swasta dan Negeri di Indonesia mengalami putus studi. Angka putus studi mahasiswa di Provinsi DKI Jakarta lebih tinggi yaitu $3.7 \%$ dan terjadi peningkatan angka putus studi di tahun 2019 yaitu 13\%.(5,6) Namun angka ini masih jauh lebih rendah dibandingkan angka putus studi pada mahasiswa kedokteran di Danish Medical School yang melaporkan bahwa $20 \%$ mahasiswa kedokteran mengalami putus studi di tahun pertamanya dalam kurun waktu tahun 1999-2000. ${ }^{(7)}$ Sampai saat ini belum ditemukan data angka putus studi khusus untuk mahasiswa Fakultas Kedokteran di Indonesia. Hal ini mungkin disebabkan karena tidak semua perguruan tinggi atau fakultas kedokteran memiliki aturan putus studi.

Fakultas Kedokteran Universitas Trisakti memiliki aturan putus studi apabila pada dua tahun pertama masa studi atau 4 semester belum menyelesaikan seluruh mata kuliah atau modul 
basic science yang seharusnya diselesaikan pada 2 semester pertama. Aturan ini tentu saja berdampak pada mahasiswa yang terkena putus studi, baik pada segi mental, sosial, dan juga ekonomi. Selain itu, dikatakan bahwa putus studi di fakultas kedokteran dapat memberikan dampak negatif untuk masyarakat, pasien, profesi dan institusi. ${ }^{(4)}$

Besarnya dampak yang timbul akibat putus studi terutama pada mahasiswa fakultas kedokteran memerlukan upaya pencegahan dan penanggulangan dari institusi pendidikan supaya dapat mengurangi masalah yang terjadi, misalnya dengan membuat program mentoring, peer mentoring, atau program remedial untuk mahasiswa yang mempunyai kelemahan dalam pembelajarannya. ${ }^{(8)}$ Menurut Karen perlu dibuat suatu program yang sistematis untuk mencegah terjadinya putus studi. Program tersebut tidak hanya terkait masalah akademik atau kognitif, tetapi juga harus mengintervensi masalah psikis dan sikap, sehingga mahasiswa dapat mencapai potensi maksimalnya di fakultas. ${ }^{(9)}$

Menyadari dampak buruk yang mungkin timbul akibat putus studi, Fakultas Kedokteran Universitas Trisakti sejak tahun 2015 membuat program remedial bagi mahasiswa yang belum mencapai kompetensi. Program ini dimaksudkan untuk memberi kesempatan pada mahasiswa mengulang ujian pada akhir modul atau pada akhir semester sehingga mereka memiliki lebih banyak kesempatan mencapai kompetensi yang telah ditetapkan dan pada akhirnya terbebas dari putus studi. Program remedial telah dilakukan lebih dari 5 tahun sehingga perlu dilakukan evaluasi untuk menilai efektivitas program tersebut apakah efektif untuk menurunkan angka putus studi pada mahasiswa fakultas kedokteran.

\section{METODE}

Penelitian dilakukan dengan desain crosssectional pada 228 mahasiswa angkatan 20132017. Data yang digunakan adalah data sekunder meliputi jenis kelamin, keterangan terancam putus studi, tahun masuk/angkatan, dan mahasiswa yang terkena putus studi. Kriteria inklusi sampel adalah mahasiswa yang termasuk pada kategori terancam putus studi atau mendapatkan surat peringatan tertulis terkait kegagalan akademik.

Analisis univariat digunakan untuk mendeskripsikan karakteristik masing-masing variabel yang diteliti, baik variabel tergantung maupun variabel bebas dalam bentuk frekuensi dan persentase, meliputi jenis kelamin, tahun masuk/angkatan dan jumlah mahasiswa putus studi. Analisis bivariat menggunakan uji Chisquare dengan tingkat kemaknaan 95\% untuk menganalisis hubungan karakteristik responden jenis kelamin dan program remedial dengan angka putus studi sehingga dapat diperoleh jika nilai $\mathrm{p}<0.05$ maka bermakna secara statistik atau menunjukkan adanya hubungan antara variabel bebas dan variabel tergantung.

\section{HASIL}

Tabel 1. Karakteristik mahasiswa terancam putus studi (Dropout/DO) tahun 2013-2017

\begin{tabular}{lcc}
\hline \multicolumn{1}{c}{ Variabel } & $\mathbf{n}$ & $\mathbf{\%}$ \\
\hline Jenis kelamin: & & \\
$\quad$ Laki-laki & 71 & 31.1 \\
$\quad$ Perempuan & 157 & 68.9 \\
Program: & & \\
$\quad$ Non-Remedial & 146 & 64.0 \\
$\quad$ Remedial & 82 & 36.0 \\
Angka putus studi: & & \\
Tidak DO & 199 & 87.3 \\
$\quad$ DO & 29 & 12.7 \\
\hline
\end{tabular}

Keterangan: $n=$ jumlah; $\%=$ persentase

Pada Tabel 1 tampak sebagian besar responden yang terancam putus studi berjenis kelamin perempuan (68.9\%), lebih banyak yang terancam putus studi pada mahasiswa program non remedial (64\%), dan angka kejadian putus studi $12.7 \%$.

Pada hasil analisis bivariat yang ditunjukkan Tabel 2, disimpulkan bahwa tidak ada perbedaan bermakna pada hubungan jenis kelamin dengan angka putus studi $(\mathrm{p}=0.989)$. Perempuan dan laki-laki memiliki peluang yang sama untuk terjadi putus studi. Walaupun secara statistik tidak bermakna $(\mathrm{p}=0.058)$, pada analisis hubungan antara program remedial dan angka putus studi didapatkan bahwa mahasiswa yang termasuk angkatan program remedial memiliki angka putus studi yang lebih tinggi (18.3\%) dibandingkan dengan mahasiswa yang termasuk angkatan nonremedial $(9.6 \%)$.

\section{PEMBAHASAN}

Secara definisi, putus studi dapat diartikan 
Tabel 2. Hubungan jenis kelamin dan program remedial dengan angka putus studi

\begin{tabular}{lcccccc}
\hline \multirow{2}{*}{ Variabel } & \multicolumn{2}{c}{ Non-DO } & \multicolumn{2}{c}{ DO } & \multirow{2}{*}{$\mathbf{p}$} \\
\cline { 2 - 5 } & $\mathbf{n}$ & $\mathbf{\%}$ & $\mathbf{n}$ & $\mathbf{\%}$ & \\
\hline Jenis Kelamin & & & & & \\
$\quad$ Laki-laki & 62 & 87.3 & 9 & 12.7 & $0.989^{*}$ \\
$\quad$ Perempuan & 137 & 87.3 & 20 & 12.7 & \\
Program & & & & & \\
$\quad$ Non-Remedial & 132 & 90.4 & 14 & 9.6 & \multirow{2}{*}{$0.058^{*}$} \\
$\quad$ Remedial & 67 & 81.7 & 15 & 18.3 & \\
\hline
\end{tabular}

Keterangan: $\mathrm{n}=$ jumlah; $\%=$ persentase; *=Uji Chi-square

sebagai putus sekolah, mengundurkan diri, atau dikeluarkan. ${ }^{(5)}$ Putus studi di fakultas kedokteran menjadi masalah karena untuk masuk ke fakultas kedokteran memerlukan biaya masuk yang besar, waktu menempuh pendidikan dan dapat mempengaruhi psikologis/emosi peserta didik yang putus studi. Peserta didik yang mengalami putus studi dapat mengalami trauma secara emosi karena merasa waktu dan biaya yang terbuang. ${ }^{(10)}$

Sampai saat ini, belum ditemukan angka putus studi pada mahasiswa fakultas kedokteran di Indonesia. Hal ini mungkin disebabkan tidak semua fakultas kedokteran menerapkan putus studi pada tahun pertama masa pendidikan. Angka putus studi pada mahasiswa Fakultas Kedokteran Universitas Trisakti tahun 20132017 sebesar $12.7 \%$. Persentase ini lebih tinggi bila dibandingkan dengan angka putus studi mahasiswa secara umum di Indonesia (2.8\%) dan DKI Jakarta (3.7\%). ${ }^{(5)}$ Terjadi peningkatan angka putus studi di DKI Jakarta pada tahun 2019 yaitu $13 \%{ }^{(6)}$ tetapi angka ini lebih rendah dibandingkan dengan angka putus studi mahasiswa fakultas kedokteran di Danish Medical School tahun 19992000.(7)

Banyak faktor yang dapat mempengaruhi terjadinya putus studi antara lain faktor sosiodemografi seperti usia pada saat masuk kuliah, jenis kelamin, suku bangsa/kebudayaan, tipe kepribadian siswa, nilai pada waktu seleksi masuk, kesulitan akademik pada tahap awal dan jenis kurikulum yang digunakan. ${ }^{(4)}$ Sekitar 10 $15 \%$ mahasiswa preklinik mempunyai kesulitan untuk menghadapi pembelajarannya. Mahasiswa dapat mengalami kegagalan pada tiga atau lebih ujian yang mereka ikuti dalam satu tahun. Faktor yang diidentifikasi sebagai penyebab kegagalan mahasiswa tersebut antara lain masalah pribadi, riwayat kesehatan, kurangnya kemampuan pada metakognitif, tidak adanya dukungan dari lingkungan sekitar, rasa enggan untuk meminta bantuan, motivasi, merasa terisolasi dari dunia luar, dan kondisi psikologis karena merasa tidak pantas meraih kesuksesan yang telah dicapainya/ imposter syndrome, sehingga mahasiswa merasa bahwa orang lain selalu lebih baik dibandingkan dirinya. ${ }^{(11)}$ Selain faktor yang berhubungan dengan mahasiswa sebagai individu, terdapat faktor lain terkait putus studi yang perlu dievaluasi seperti sosiodemografi, populasi, lingkungan, pengajar, suasana akademik, dan kurikulum. ${ }^{(12)}$

Walaupun secara statistik tidak didapatkan hubungan yang bermakna antara jenis kelamin dengan angka putus studi ( $\mathrm{p}=0.989)$, namun jumlah mahasiswa yang terancam putus studi lebih banyak berjenis kelamin perempuan. Hasil ini sejalan dengan penelitian Doll JJ yang menyatakan bahwa angka putus studi pada perempuan lebih tinggi dibandingkan laki-laki. Dijelaskan bahwa mahasiswa perempuan selama masa studinya dapat saja terganggu dengan urusan menikah dan melahirkan, sehingga tidak dapat menyelesaikan pendidikan dan akhirnya putus studi. ${ }^{(12)}$ Hasil yang berbeda dinyatakan oleh Lavoie yang mendapatkan angka putus studi lebih tinggi terjadi pada lakilaki dibandingkan perempuan, karena pengaruh tingkat stres pada pada laki-laki yang lebih tinggi dibanding perempuan, sehingga mempengaruhi kemampuan akademiknya. ${ }^{(13)}$ Demikian pula Grainger dalam penelitiannya menyatakan bahwa mahasiswa laki-laki mempunyai risiko putus studi lebih tinggi dibandingkan mahasiswa perempuan, sehingga mahasiswa laki-laki lebih banyak mengikuti program remedial di tahun pertama dan kedua masa pendidikan mereka. ${ }^{(14)}$

Terdapat berbagai upaya yang 
direkomendasikan untuk menurunkan angka putus studi, seperti membuat ujian saringan masuk yang ketat, memperbaiki kurikulum dan metode pembelajaran, memfasilitasi program mentoring dan peer-mentoring, pemberian umpan balik yang konstruktif, dan penyelenggaraan program remedial. ${ }^{(15,16)}$ Peer mentoring program nantinya diharapkan akan memberikan intervensi pada pemahaman serta manajemen waktu mahasiswa yang nanti akan menjadikan mahasiswa menjadi aktif dalam pembelajaran. ${ }^{(17)}$

Hampir seluruh fakultas kedokteran menyelenggarakan ujian seleksi mahasiswa baru untuk mendapatkan kriteria minimal yang dibutuhkan dalam menempuh pendidikan kedokteran. Nilai tes penerimaan masuk dengan metode seleksi yang tepat dikatakan menurunkan angka putus studi. ${ }^{(7,11)}$ Dalam penelitian yang dilakukan oleh Glauser dikatakan seleksi penerimaan masuk yang ketat dapat mencegah terjadinya putus studi dan menyebabkan rendahnya angka putus studi Fakultas Kedokteran di Kanada. (15) Hasil tes penerimaan masuk mempunyai korelasi yang kuat untuk memprediksi performa mahasiswa selama masa pendidikannya, sehingga nantinya mahasiswa tersebut dapat diprediksi mengikuti program remedial atau tidak. ${ }^{(14)}$

Program mentoring oleh dosen pembimbing akademik ataupun peer mentoring dan program remedial untuk mahasiswa yang mempunyai kelemahan dalam pembelajarannya dapat menurunkan angka putus studi. ${ }^{(8)}$ Program Peer mentoring sebaiknya dilakukan sejak mahasiswa menjalani masa pendidikannya sehingga mentor dapat membantu mahasiswa beradaptasi dengan lingkungan pembelajarannya. Program ini secara statistik berhubungan dengan peningkatan kemampuan kognitif mahasiswa, sehingga nilai mahasiswa/ nilai indeks prestasi meningkat. ${ }^{(17)}$ Program remedial dalam pendidikan kedokteran adalah tindakan untuk menfasilitasi peserta didik yang performanya di bawah standar. ${ }^{(13)}$ Namun, hasil penelitian ini didapatkan tidak terdapat hubungan yang signifikan antara program remedial dengan terjadinya putus studi $(\mathrm{p}=0.058)$. Angka putus studi pada mahasiswa dengan program remedial (18.3\%) lebih tinggi dibandingkan dengan mahasiswa program non remedial (9.6\%). Hasil penelitian ini tidak sesuai dengan hasil penelitian Kalet dan Chou yang menyatakan program remedial dapat menurunkan angka terjadinya putus studi pada fakultas kedokteran. (10) Penelitian Stegers-Jager menyatakan program remedial bertujuan untuk mencegah terjadinya putus studi tetapi harus terdapat intervensi terhadap masalah akademik dan tingkah laku kepada mahasiswa yang terancam putus studi. Intervensi pada kognitif/pengetahuan mahasiswa diharapkan dapat membantu mahasiswa mencapai potensi maksimalnya di fakultas. ${ }^{(9)}$

Keberhasilan suatu program remedial tergantung pada standar keberhasilan yang ditetapkan pada awal program dan keterlibatan atau dukungan penuh dari fakultas serta pengajar. ${ }^{(18)}$ Pengajar harus memiliki tanggung jawab pada mahasiswa yang membutuhkan dukungan secara akademik dan personal sehingga mahasiswa tidak hanya sekadar meningkatkan hasil belajar tetapi juga meningkatkan performa mereka secara keseluruhan. Hal ini membutuhkan waktu yang lebih lama untuk memonitor mahasiswa yang diikutkan dalam program sehingga dibutuhkan komitmen besar dari fakultas dan pengajar. Pengajar yang diikutsertakan dalam program ini harus membina hubungan yang baik dan memberikan umpan balik yang konstruktif kepada peserta program. ${ }^{(11,16)}$

Pemberian umpan balik merupakan salah satu aspek yang efektif dalam pendidikan kedokteran. Pemberian umpan balik yang konstruktif dapat meningkatkan motivasi mahasiswa dan merupakan komponen dari pembelajaran sepanjang hayat (life long learning). Umpan balik yang konstruktif dapat membantu mahasiswa mencapai hasil yang maksimal dalam pembelajaran, tingkah laku, dan performa mahasiswa secara keseluruhan. Umpan balik dapat diberikan secara tertulis atau pun verbal, secara individu maupun kelompok, dan hubungan yang dekat antara mahasiswa dengan pengajar akan lebih memudahkan mahasiswa untuk menerima umpan balik secara positif. ${ }^{(19,20)}$

Motivasi juga menjadi faktor penting untuk mahasiswa melakukan pembelajarannya. Motivasi akan mendorong mahasiswa untuk mencapai kemampuan diri yang maksimal. Motivasi ini sebaiknya sudah terbentuk sejak pendidikan menengah, sehingga ketika mahasiswa tersebut berada di perguruan tinggi, motivasi tersebut dapat membantunya melakukan 
pembelajaran. Motivasi ini diharapkan nantinya dapat menurunkan terjadinya putus studi. ${ }^{(21)}$

Berdasarkan hasil penelitian Vergel, perbedaan desain kurikulum dari kurikulum tradisional/teacher centered dengan kurikulum terintegrasi menjadi salah satu faktor terjadinya putus studi. Kurikulum terintergrasi menurunkan angka terjadinya putus studi pada fakultas kedokteran karena kurikulum ini menanamkan pemahaman pentingnya profesionalisme seorang dokter, terintergrasinya ilmu biomedik dengan ilmu kedokteran klinik, pengaturan kurikulum berdasarkan sistem organ., menekankan pembelajaran aktif yang terintegrasi, dan memperhatikan validitas dan reliabilitas sistem penilaian pembelajaran. ${ }^{(8)}$

Penelitian ini memiliki keterbatasan yaitu belum mengidentifikasi faktor-faktor lain yang dapat mempengaruhi putus studi, seperti nilai seleksi penerimaan, faktor psikologis, keluarga, tempat tinggal, motivasi, program mentoring, dan peer-mentoring.

\section{KESIMPULAN}

Angka putus studi di Fakultas Kedokteran Universitas Trisakti pada Angkatan 20132017 sebesar $12.7 \%$. Tidak terdapat hubungan bermakna antara jenis kelamin dan program remedial dengan terjadinya putus studi. Perlu diidentifikasi faktor lain yang dapat menjadi risiko mahasiswa terancam putus studi, seperti faktor psikologi, keluarga, nilai seleksi masuk, motivasi, sehingga dapat dilakukan intervensi yang tepat pada program remedial. Institusi perlu merancang program remedial yang tidak hanya menekankan aspek kognitif tetapi harus dapat melakukan program yang dapat mengintervensi psikis dan sikap agar mahasiswa dapat mencapai kompetensi maksimal yang diharapkan.

\section{UCAPAN TERIMA KASIH}

Fakultas Kedokteran Universitas Trisakti sebagai lokasi penelitian.

\section{REFERENSI}

1. Konsil Kedokteran Indonesia. Standar Kompetensi Dokter Indonesia. 2nd ed [Internet]. Jakarta: Konsil Kedokteran Indonesia; 2012. Available from: http:/www.kki.go.id/assets/data/arsip/ SKDI_Perkonsil,_11_maret_13.pdf

2. Kemenristekdikti RI. Peraturan Menteri Riset,
Teknologi, dan Pendidikan Tinggi Republik Indonesia Nomor 18 Tahun 2018 tentang Standar Nasional Pendidikan Kedokteran [Internet]. Jakarta: Kemenristekdikti RI; 2018. Available from: http://www.kki.go.id/assets/data/arsip/ Permenristekdikti-No-18-Tahun-2018.pdf

3. Kemenristekdikti RI. Peraturan Menteri, Riset, Teknologi, dan Pendidikan Tinggi Republik Indonesia Nomor 44 Tahun 2015 tentang Standar Nasional Pendidikan Tinggi [Internet]. Jakarta: Kemenristekdikti RI; 2015. Available from: https:// lldikti13.kemdikbud.go.id/2016/01/26/standarnasional-pendidikan-tinggi-tahun-2015/

4. O'Neill LD, Wallstedt B, Eika B, et al. Factors associated with dropout in medical education: A literature review. Med Educ. 2011;45(5):440-54. doi: 10.1111/j.1365-2923.2010.03898.x

5. Kemenristekdikti RI. Statistik Pendidikan Tinggi 2017. Jakarta: Kemenristekdikti RI; 2017.

6. Kemenristekdikti RI. Statistik Pendidikan Tinggi 2019. Jakarta: Kemenristekdikti RI; 2019.

7. Mørcke AM, O’Neill L, Kjeldsen IT, et al. Selected determinants may account for dropout risks among medical students. Dan Med J. 2012;59(9):A4493. PMID: 22951195

8. Vergel J, Quintero GA, Isaza-Restrepo A, et al. The influence of different curriculum designs on students' dropout rate: a case study. Med Educ Online. 2018;23(1):1432963. doi: 10.1080/10872981.2018.1432963

9. Stegers-Jager KM, Cohen-Schotanus J, Themmen APN. The Four-Tier Continuum of Academic and Behavioral Support (4T-CABS) model: An integrated model for medical student success. Acad Med. 2017;92(11):1525-30. doi: 10.1097/ ACM.0000000000001685

10. Kalet A, Chou CL. Remediation in Medical Education [Internet]. New York: Springer; 2014. 3-14 p. doi: 10.1007/978-1-4614-9025-8

11. Shankar N, Ravindranath $Y$, Ravindranath $R$, et al. Effects of targeted remediation in anatomy for first year medical students. Anat Cell Biol. 2019;52(1):57-68. doi: 10.5115/acb.2019.52.1.57

12. Doll JJ, Eslami Z, Walters L. Understanding why students drop out of high school, According to their own reports: Are they pushed or pulled, Or do they fall out? a comparative analysis of seven nationally representative studies. SAGE Open. 2013;3(4):1-15. doi: 10.1177/2158244013503834

13. Lavoie L, Dupéré V, Dion E, et al. Gender Differences in Adolescents' Exposure to Stressful Life Events and Differential Links to Impaired School Functioning. J Abnorm Child Psychol. 2019;47(6):1053-64. doi: 10.1007/s10802-01800511-4

14. Grainger B, Yielder J, Reid P, et al. Predictors of medical student remediation and their underlying causes: early lessons from a curriculum change in the University of Auckland Medical Programme. N Z Med J. 2017;130(1460):73-82. PMID: 28796773.

15. Glauser W. Why do students quit medical school far less often in Canada than in other countries? CMAJ. 2019;191(6):E174-5. doi:10.1503/ cmaj.109-5704

16. Kalet A, Guerrasio J, Chou CL. Twelve tips for 
developing and maintaining a remediation program in medical education. Med Teach. 2016;38(8):78792. doi: 10.3109/0142159X.2016.1150983

17. Arco-Tirado JL, Fernández-Martín FD, FernándezBalboa JM. The impact of a peer-tutoring program on quality standards in higher education. High Educ. 2011;62(6):773-88. doi: 10.1007/s10734011-9419-X

18. Rumburger RW. Dropping Out. Why Students Drop Out of High School And What Can Be Done About It. England: Harvard University Press; 2011.

19. Aldowah H, Al-Samarraie H, Alzahrani AI, et al. Factors affecting student dropout in MOOCs: a cause and effect decision-making model. J Comput High Educ. 2020;32(2):429-54. doi: 10.1007/ s12528-019-09241-y

20. Bowen L, Marshall M, Murdoch-Eaton D. Medical Student Perceptions of Feedback and Feedback Behaviors Within the Context of the "educational Alliance." Acad Med. 2017;92(9):1303-12. doi: 10.1097/ACM.0000000000001632

21. Fan W, Wolters CA. School motivation and high school dropout: The mediating role of educational expectation. Br J Educ Psychol. 2014;84(1):2239. doi: 10.1111/bjep.12002 